\title{
Hang the Kaiser! But for What, and Would It Be Justice?
}

\author{
Paul Mevis \& Jan M. Reijntjes*
}

\begin{abstract}
The Versailles Treaty (Art. 227) called for the prosecution of Wilhelm II, the German ex-Kaiser. Because of the refusal of the Dutch Government to surrender Wilhelm, a trial never took place. This paper tries to elaborate some questions concerning this possible trial. What was the background of the said Treaty paragraph? What would have happened when Wilhelm had been surrendered? Based on a report of a special committee to the peace conference, the possible indictment is discussed. The authors try to elaborate some thoughts for answering the question about Wilhelm's criminal responsibility, especially as author of the war ('ius ad bellum') by starting an aggressive war and/or by violating the neutrality of Belgium and Luxemburg. Wilhelm's possible responsibility for violations of the 'ius in bello' (laws and customs of war) in Belgium, France, and Poland and/or by ordering an unlimited submarine war is discussed as well. It is concluded that it would have been very difficult for the tribunal to have Wilhelm find criminal responsible for the indictment, except for the violation of the neutrality of Belgium and Luxemburg. But then, the tribunal would have been obliged to answer fundamental questions about the command responsibility of Wilhelm. From a point of view of international criminal law, it is rather unfortunate that the unique opportunity for a 'Prologue to Nuremberg' was not realised, although a trial would not have made history take a different turn than it did in the twentieth century after the 'Great War'.
\end{abstract}

Keywords: The Versailles Treaty, Kaiser Wilhelm II, indictment, international criminal law

It was nearly a hundred years ago that the First World War (a.k.a. the Great War) started. Its causes and the responsibility for its outbreak are still under serious debate. However, at the end of the war the Allied and Associated Powers made one thing very clear: in their eyes the main culprit was the German Kaiser, Wilhelm II, and he should be prosecuted for what he had done. Art. 227 of the Versailles Treaty could not be misunderstood:

\footnotetext{
P.A.M. Mevis is professor of criminal law at the Erasmus University Rotterdam. Prof. Mevis wrote before 'De berechting van Wilhelm II', in J. Dohmen, T. Draaisma \& E. Stamhuis (ed.), Een kwestie van grensoverschrijding. Liber amicorum P.E.L. Janssen (2009), at 197-231. J.M. Reijntjes is professor of (international) criminal law at the University of Curaçao.
}

The Allied and Associated Powers publicly arraign William II of Hohenzollern, formerly German Emperor, for a supreme offence against international morality and the sanctity of treaties.

A special tribunal will be constituted to try the accused, thereby assuring him the guarantees essential to the right of defence. It will be composed of five judges, one appointed by each of the following Powers: namely, the United States of America, Great Britain, France, Italy and Japan.

In its decision the tribunal will be guided by the highest motives of international policy, with a view to vindicating the solemn obligations of international undertakings and the validity of international morality. It will be its duty to fix the punishment which it considers should be imposed.

The Allied and Associated Powers will address a request to the Government of the Netherlands for the surrender to them of the ex-Emperor in order that he may be put on trial.

A request to the Dutch government for Wilhelms' surrender had been made necessary by his flight; on 10 November 1918 the - soon former ${ }^{1}$ - Kaiser had crossed the Dutch borders. It seems that the French prime minister, Clemenceau, acting on behalf of the Allied and Associated Powers (hereafter Allied Powers), shortly after conclusion of the Treaty, on 28 June 1919, for the first time requested the extradition of the Kaiser - a request that, however, was politely refused. ${ }^{2}$ Of

1. His abdication was published 9 Nov. 1918 in the Reichs-Anzeiger, only signed by the Reichskanzler; it was followed by a more formal abdication on 28 Nov. 1918, published 30 Nov. 1918 in the Reichs-Anzeiger.

2. A second request (also signed by Clemenceau) followed on 15 Jan. 1920 and was refused on 21 Jan. 1920, and a last request (signed by Lloyd George) was made on 14 Feb. 1920, refused on 2 March 1920 (texts in French in Weekblad van het Recht, no. 10511 and 10529 , German translation in Sebastian Haffner a.o., Der Vertrag von Versailles (1988), at 392-98. It seems that Lloyd George in a final note of 30 March 1920 made the Dutch Government responsible for all the consequences that might follow from the presence of the ex-Kaiser in the Netherlands (G. Hankel, Die Leipziger Prozesse (2003), at 870). See also e.g. J.F. Willis, Prologue to Nuremberg. The Politics and Diplomacy of Punishing War Criminals of the first World War (1982), especially at 66-68, N. Ashton and D. Hellema, " "Hang the Kaiser! " De Brits-Nederlandse betrekkingen en het lot van ex-keizer Wilhelm II, 1918-1920', in D.A. Hellema e.o. (ed.), Buitenlandse Zaken, Vierde Jaarboek voor de geschiedenis van de Nederlandse buitenlandse politiek in de twintigste eeuw (1998), at 75-93, M. Wester, 'Hang the Kaiser', SKRIPT no. 2 (1997) and A.H. Klip, 'De keizer-kwestie, over een uitlevering die niet doorging', in C. Kelk, F.A.M.M. Koenraadt \& D. Siegel (eds.), Veelzijdige gedachten. Liber amicorum prof.dr. Chrisje Brants (2013), PompeSeries vol. 75, at 95-106 (with more literature). 
course, the Allied Powers could have tried Wilhelm in absentia, but obviously they did not want to do so; although it has never been clarified whether they even discussed this option, it may be assumed that it was highly repulsive to American and British legal minds. ${ }^{3}$ But what would have happened when the Kaiser had been surrendered? For the Allied Powers there would have been no way back; without any doubt the Kaiser was put on trial. But would there have been crimes for which he could be convicted? And if so, what might have been the sanction? We do not think that an attempt to answer these questions will amount to pure speculation; ${ }^{4}$ but it will be no easy task, either. Answering such questions requires some knowledge of the history of the Versailles treaty, but above all it will lead us to the opinions of the academic community in the field of international (criminal) law in those times, buried in many books. Has such an exercise any use? We think it does; it reveals the 'prehistory' of international (criminal) law. We will meet many problems that are still actual today; studying them in the context of the Great War could help us to understand them. But the most intriguing question of all is: would the trial of the Kaiser have accelerated the development of the law in this field, and if so, on which points? Of course, it will not be possible to provide answers in a simple essay like this; but we will try to give an outline of what could be expected from such research.

\section{Hanging the Kaiser}

Shortly after the war, prosecution of the Kaiser was an important issue in French and British politics. Especially the British prime ministers Asquith and Lloyd George were clamorous. In December 1918, Lloyd George went into the elections under the cry: Hang the Kaiser! This created the impression that for him the result of a trial would be a sentence of death. Obviously he thought this was what the voters wished, too. Another outcome would have been rather embarrassing. Could a trial under such circumstances have been fair and impartial? If ever a prosecution would have deserved the disqualification 'political', it was the prosecution of the Kaiser. However, the extradition of the Kaiser was not refused on the generally accepted political offense exception, nor on its later offshoot, the prospective unfairness of the prosecution for its political character. The Dutch government probably thought it unwise to irate the Allied Powers by using such arguments and preferred to avoid them. This was facilitated by the decision of the Allies not to invoke existing extradition treaties but to base their claim on the Versailles Treaty itself. However, as could have been expected, because

3. Clemenceau thought a trial in absentia quite possible; see D.L. George, The Truth about the Peace Treaties (1920), vol. I, at 98.

4. Otherwise G.S. Viereck, The Kaiser on Trial (1937). The author reports in his book the trial of Wilhelm II as he imagined it would have been, witness statements included. the Netherlands were no party to the Treaty, they felt not bound by it. Probably not all the Allies deplored this very much: in any case they had the Kaiser out of their way and his prosecution could only have led to embarrassment. Even Lloyd George, when confronted with his former election cry, seems to have answered: I only wanted to hang him to the electoral gallows. ${ }^{5}$

\section{The Indictment}

In the Versailles Treaty, the Allied Powers stated that the Kaiser should be prosecuted for a supreme offence against international morality and the sanctity of treaties. What did they mean, and where did this formula come from?

The Preliminary Peace Conference decided at its plenary session of 25 January 1919 to create, for the purpose of inquiring into the responsibilities relating to the war, a Commission on the Responsibility of the Authors of the War and on Enforcement of Penalties (hereafter Commission on Responsibility), composed of fifteen members. ${ }^{6}$ It was charged to inquire into and report upon the following points:

1. the responsibility of the authors of the war;

2. the facts as to breaches of the laws and customs of war committed by the forces of the German Empire and their Allies, on land, on sea, and in the air during the present war;

3. the degree of responsibility for these offences attaching to particular members of the enemy forces, including members of the General Staffs and other individuals, however highly placed;

4. the constitution and procedure of a tribunal appropriate for the trial of these offences;

5. any other matters cognate or ancillary to the above which may arise in the course of the enquiry, and which the Commission finds useful and relevant to take into consideration.

In its report ${ }^{7}$ of 29 March 1919, the Central Powers were brandmarked for authoring the war, for violating the neutrality of Belgium and Luxemburg, guaranteed by treaty, and for carrying on the war by illegitimate methods in violation of the established laws and customs of war and the elementary laws of humanity. However, the Commission found that it would not make much

5. A. Ribot, Journal et Correspondances inédites (1936), at 294 ('une potence électorale')

6. See e.g. Willis, above n. 2, at 68-79 and M.C. Bassiouni, 'World War I: "The War to End All Wars' and the Birth of a Handicapped International Criminal Justice System', Denver Journal of International Law at 244-91, on 253-55 (2001/2002). Interesting detail: from the French government the Preliminary Conference had received a detailed report by two eminent lawyers on the difficulties connected with prosecuting the Kaiser, later published as A. de Lapradelle and F. Larnaude, 'Examen de la responsibilité pénale de I'empereur Guillaume II d'Allemagne', Journal de Droit International, at 131-59 (1919).

7. Published in 14 American Journal of International Law, at 95-154 (1920). 
sense to prosecute for starting an aggressive war in itself:

the premeditation of a war of aggression, dissimulated under a peaceful pretence, then suddenly declared under false pretexts, is conduct which the public conscience reproves and which history will condemn, but by reason of the purely optional character of the institutions at The Hague for the maintenance of peace (International Commission of Inquiry, Mediation and Arbitration) a war of aggression may not be considered as an act directly contrary to positive law, or one which can be successfully brought before a tribunal $(\ldots)^{8}$

For that reason the Kaiser, in the opinion of the Commission, should not be prosecuted for the acts which brought about the war, neither for the breaches of the neutrality of Belgium and Luxemburg. The Commission held the opinion that these breaches were 'a highhanded outrage (...) upon international engagements, deliberately, and for a purpose which cannot justify the conduct of those who were responsible', but also thought that they should only be made the subject of a formal condemnation by the Peace Conference. Unmistakably the Commission saw breaches of the ius ad bellum not yet as a criminal act but as an act that should be made so. 'It is desirable that for the future penal sanctions should be provided for such grave outrages against the elementary principles of international law. ${ }^{9}$ However, with regard to the ius in bello the Commission found:

All persons belonging to enemy countries, however high their position may have been, without distinction of rank, including Chiefs of States, who have been guilty of offences against the laws and customs of war or the laws of humanity, are liable to criminal prosecution. $^{10}$

Here the Kaiser had been included because 'the trial of the offenders might be seriously prejudiced if they attempted and were able to plead the superior orders of a sovereign against whom no steps had been or were being taken.' 11

The politicians ${ }^{12}$ however kept to their opinion that the former Kaiser should (also) be tried for his responsibility as author of the war. They shared 'a growing feeling that war itself was a crime against humanity'; 13 thus bringing the case against the Kaiser into court also stood

8. Report, AJIL, at $118(1920)$

9. Report, above n. 8, at 120 .

10. Report, above n. 8, at 117

11. Report, above n. 8 , at 117

12. The British Attorney-General sir Frederick Smith (see George, above n. 3, at 98-99) and Lord Birkenhead included (see the interesting opinion of the latter, reprinted in George, above n. 3, at 102-12). More in Willis, above n. 2, chapter 5, George, above n. 3, and M. MacMillan, Peacemakers. The Paris Conference of 1919 and Its Attempt to End War (2001).

13. Lloyd George, above n. 3, at 96. for 'a new world order'. ${ }^{14}$ Obviously they expected that his prosecution would be followed by a conviction. Especially the French did not doubt such an outcome. ${ }^{15}$ As to the question whether waging an aggressive war was a criminal act, they were in good company: the American members of the Commission, disagreeing with the majority, believed that

any nation going to war assumes a grave responsibility, and that a nation engaging in a war of aggression commits a crime. They hold that the neutrality of nations should be observed, especially when it is guaranteed by a treaty to which the nations violating it are parties, and that the plighted word and the good faith of nations should be faithfully observed in this as in all other respects. ${ }^{16}$

The only reason why the Americans did not formally dissent from the conclusions of the Commission on the ius ad bellum was 'the difficulty of determining whether an act is in reality one of aggression or of defence'. As an afterthought, they added that a head of state only is responsible to the law of his own country, unless he has abdicated or has been repudiated by his people (by then both applied to the Kaiser). What to do with defeated heads of state was a question for statesmen, not for judges to decide; their offences were of a political nature and should therefore be met by political sanctions ${ }^{17}$ (obviously they had in mind the option of sending the Kaiser to a place like the Falkland Islands, as Napoleon had been sent to Saint Helena). In England, Lord Birkenhead said:

the ex-Kaiser ought to be punished, either by way of trial or as Napoleon was punished. (Some people incline) to the first of those courses, namely that he should be tried. I am not at present wholly convinced upon this point (but) I say quite plainly that I should feel the greatest difficulty in being responsible in any way for the trial of subordinate criminals if the exKaiser is allowed to escape. ${ }^{18}$

In any case, a judgment by politicians was what the politicians, after some debate, decided not to give. They found that the Kaiser should be prosecuted for his breaches of the ius ad bellum, to wit supreme offences against international morality and the sanctity of treaties, before an independent international court, and that he would have a fair trial. Even after a four-year war and millions of deaths, such a court - in their opinion could be found, and fairness of the procedure could be

14. Willis, above n. 2, at 3-4.

15. Obviously they leaned heavily on De Lapradelle/Larnaude, who solved many problems by declaring: 'Un droit international nouveau est né' (above n. 6 at 144). Exemplary for the French post-war literature on the subject is their sneer on the ex-Kaiser, 'déserteur de sa propre armée' at 137. In the same style A. Mérignhac and E. Lémonon, Le Droit des Gens et la Guerre de 1914-1918 2 (1921).

16. Report, above n. 8, at 140.

17. Report, above n. 8, at 136 .

18. Cited by Lloyd George, above n. 3, at 112-13. 
guaranteed. Clemenceau seems to have answered the American president Wilson, when he expressed his fear that a trial would be infected by emotions: Nothing is accomplished without emotion. Was Jesus Christ not carried away by passion the day he chased the money changers from the Temple?' 19 In other words, even emotional actions can be just and have just results. No Siegerjustiz! Especially Lloyd George thought that fair proceedings in which the rights of the defence would be sufficiently guaranteed would help in further developing international criminal law. He even suggested to invite the young German Republic to participate in the tribunal that would be formed and added: 'I have no doubt she will send men, in her present state, who will judge the ex-Kaiser very impartially.'20

At the same time, as advised by the Commission on Responsibilities, the Kaiser would be prosecuted, together with other 'war criminals', for breaches of the ius in bello, that is for acts in violation of the lams and customs of mar. This was based on Art. 228 of the Versailles Treaty:

The German Government recognises the right of the Allied and Associated Powers to bring before military tribunals persons accused of having committed acts in violation of the laws and customs of war. Such persons shall, if found guilty, be sentenced to punishments laid down by law. This provision will apply notwithstanding any proceedings or prosecution before a tribunal in Germany or in the territory of her allies.

The German Government shall hand over to the Allied and Associated Powers, or to such one of them as shall so request, all persons accused of having committed an act in violation of the laws and customs of war, who are specified either by name or by the rank, office or employment which they held under the German authorities. ${ }^{21}$

Retribution was the main object of these clauses; the Allied powers already had brought captive German officers $^{22}$ to justice who had breached the laws and customs of war, but they wanted also to try culprits who were not (yet) in their power. Emphasising the validity of the pre-war ius in bello, as it had been written in the Hague Conventions and as it would be found in customary law, could be seen as a second motive.

The Commission on Responsibility found that the war had been carried on 'by barbarous or illegitimate methods in violation of the established laws and customs of war and the elementary laws of humanity'. ${ }^{23}$ Its report

19. Cited from Willis, above n. 2, at 78

20. Lloyd George, above n. 3, at 100.

21. Both Art. 227 and Art. 228 were included in Part VII of the Treaty, on Penalties. Stipulations comparable with Art. 228 were included in the Treaties of Saint Germain (with Austria, Sept. 1919), Neuilly (with Bulgaria, Nov. 1919) and Sèvres (with Turkey, 1920, never ratified).

22. For example, the lieutenants Von Schierstaedt and Von Strachwitz, sentenced on 1 Oct. 1914 for looting (R. Poincaré, 'Au service de la France. Neuf années de souvenirs, Les tranchées 6, at 145-46 (1930)).

23. Report, above n. 8, at 115. leaves no doubt that, in the opinion of its majority, the Kaiser should not be prosecuted for breaches of the ius ad bellum, but for the German infringements upon the ius in bello. Only the American and the Japanese members disagreed even on this point, mainly because they did not want to prosecute for offences that had not been directly ordered by the Kaiser. They strongly disliked what they called the doctrine of negative criminality, based on criminal liability for mere abstention from preventing violations of the laws and customs of war and of humanity. There is no reason why the politicians would not have followed the Commission on this point. That the Kaiser is only mentioned in Art. 227 of the Treaty, and not in Art. 228, may not be used as an argument why it would not be acceptable to prosecute him also under Art. 228; but did the politicians also adopt negative responsibility?

The Commission on Responsibility recommended to base a prosecution for violations of the laws and customs of war on 'the principles of the law of nations as they result from the usages established among civilized peoples, from the laws of humanity and from the dictates of public conscience'. ${ }^{24}$ Unmistakably these criteria have been inspired by the so-called Martens clause in the pre-amble of the second 1899 Hague treaty, repeated in the pre-amble of the fourth 1907 Hague treaty:

En attendant qu'un Code plus complet des lois de la guerre puisse être édicté, les Hautes Parties contractantes jugent opportun de constater que, dans les cas non compris dans les dispositions réglementaires adoptées par Elles, les populations et les belligérants restent sous la sauvegarde et sous l'empire des principes du droit des gens, tels qu'ils résultent des usages établis entre les nations civilisées, des lois de l'humanité et des exigences de la conscience publique.

It was probably to appease the Americans that the laws of humanity in the end did not appear in the Versailles treaty; they thought that 'the laws of humanity do not constitute a definite code with fixed penalties which can be applied through judicial process' ${ }^{25}$ This means that the indictment against Wilhelm II could have been the following: (see Table on next page).

Before we ask ourselves what a court would have decided, another question has to be answered: was a trial not superfluous? Had the new German Republic not accepted its war guilt? Art. 231 of the Versailles treaty reads:

The Allied and Associated Governments affirm and Germany accepts the responsibility of Germany and her allies for causing all the loss and damage to which the Allied and Associated Governments and their nationals have been subjected as a consequence of the war imposed upon them by the aggression of Germany and her allies.

24. Report, above n. 8, at 122.

25. R. Lansing, 'Some Legal Questions of the Peace Conference', American Journal of International Law, 631-50, at 647(1919). 


\begin{tabular}{|c|c|}
\hline A & ius ad bellum \\
\hline count 1 & $\begin{array}{l}\text { starting an aggressive war against Russia, France, and other countries (according to Art. 227: a supreme offence against } \\
\text { international morality) }\end{array}$ \\
\hline count 2 & $\begin{array}{l}\text { ordering or at least condoning violation of the neutrality of Belgium and Luxemburg (according to Art. 227: a supreme } \\
\text { offence against international morality and the sanctity of treaties) }\end{array}$ \\
\hline B & ius in bello \\
\hline count 3 & ordering or at least not preventing violations of the laws and customs of war, especially in Belgium, France, and Poland.* \\
\hline count 4 & declaring an unlimited submarine war \\
\hline
\end{tabular}

* The Commission gave a list of 32 categories (Report, above n. 8, at 114-15); see for their basis in law Bassiouni, above n. 6, at 260-61.

Allied politicians eagerly used this text to assure their adherents that the time to discuss German guilt had passed: they had the German confession black on white. This, however, is utter nonsense. Of course, an extorted confession is worthless, even when extorted by treaty, and never could the Republic confess on behalf of the Kaiser; but neither did they confess on behalf of the former Reich. It is not without importance that Art. 231 is not a part of chapter 7 of the treaty, on penalties, but of chapter 8 , on reparations. There the Republic promised to pay the bill for the war and conceded they had started the actual fighting (which was quite clear) and could therefore be called 'aggressors'; but guilt - criminal or only moral guilt - is quite something else. All that may be deducted from Art. 231 is civil responsibility. ${ }^{26}$

\section{Criminal Liability}

What was the discussion, whether the Kaiser could be prosecuted for waging war, really about? We already distinguished the ius in bello from the ius ad bellum. An important part of the ius in bello had been defined in the 1907 Hague treaties; insofar there were clear and mostly unambiguous norms - but could infringements upon these norms be punished criminally? And probably there was still an unwritten part of the ius in bello left, on the customs of the war on sea, for example. The ius ad bellum, to the contrary, never had been defined; some authors even doubted its existence (they thought that the decision to start a war was not governed by law), but if it existed, it was dubious whether infringements could be punished. The 'special tribunal' as foreseen in Art. 227 of the treaty would have to break its own way, leaning on the existing literature. Inspecting this literature, the tribunal would find that, although the famous Emerich de Vattel, probably the most studied and the

26. Compare C. Schmitt, Das international-rechtliche Verbrechen des Angriffskrieges unter der Grundsatz 'Nullum crimen, nulla poena sine lege', 1945, esp. part II, 'Kriegsverbrechen und Kriegsschuld im Versailler Vertrag' (published again and commented by Helmut Quaritsch, Duncker \& Humblot, Berlin (1994)), at 157. most cited author after Hugo Grotius, indeed did defend that waging an unjust war could be punished by the victor ${ }^{27}$ - it would also find that this view soon lost most of its support. In the nineteenth century, it even was an issue whether infringements upon the ius in bello could be punished; authors like G.-F. von Martens, ${ }^{28}$ Bluntschli, ${ }^{29}$ and Van Vollenhoven ${ }^{30}$ defended this, and it was confirmed by the Manuel des lois de la guerre sur terre, drawn up in 1880 by the Institut de Droit International at Brussels, but others flatly denied the point.

In former times, anyone who went down in battle and could not save himself by flight had to surrender unconditionally. The victorious party could freely dispose of its captive enemies. Usually there was no hesitation to incarcerate, banish, or even execute the former opponents without any form of procedure when it was thought that this would serve the victors interests; even more so, when the captives were accused of evil deeds. Thus Napoleon I was banished to Elba and later imprisoned on Saint Helena. From this, a rule of customary law could be derived, saying that whoever misbehaved in war and succumbed to his opponent could be sanctioned by him. In that case, it would be a step forward not simply to imprison the Kaiser for life on the Falkland Islands but to try him before an independent court under strict rules of procedure, guaranteeing his rights to defend himself effectively. ${ }^{31}$

In this line of reasoning, it becomes clear why under such circumstances the nullum crimen rule does not apply - in any case not in the strict sense in which it is used by criminal lawyers. Of course, there has to be a

27. E. de Vattel, Le Droit des Gens, ou Principes de la Loi Naturelle, Appliqués à la conduite \& aux affaires des Nations \& des Souverains (1758), e.g. book $2 \S 52$ and book $3 \S 185$.

28. Précis de Droit des Gens moderne de l'Europe (1788); we used the edition published by Guillaumin, Paris 1864, Vol. 2, at 232.

29. J.C. Bluntschli, Das moderne Kriegsrecht der civilisirten Staaten, Beck, Nördlingen, 2nd edn. (1874), I.1 (1st edn. 1866).

30. J.C. van Vollenhoven, Omtrek en inhoud van het internationale recht, PhD-thesis (1898).

31. Some authors draw our attention to what they define as different development, to wit offering amnesty in peace treaties. 'No real peace without forgiveness'. That, however, is quite another disussion, the opposing point of view being: No real peace without justice. It would bring us to South Africa and South America. 
clear norm of behaviour; nobody should be punished for his activities when he could not know that they were not allowed. But why would it not be sufficient that he is aware of the consequences which his acts could have if he would be caught? In fact, he benefits by granting him a criminal trial instead of a lynching. But what about the punishment? Again it seems sufficient when it lies within the range of possibilities that could be foreseen: a fine, imprisonment for some time or for life, or execution.

This underlines that here international law has to define the limits of liability, not (classic) criminal law. It is axiomatic that prosecutions under international law are not subjected to legality in the strict sense of a requirement of well-defined prohibitions. Foreseeability is sufficient. Criminal law, in such cases, only has to provide a procedure. As soon as international customary law has developed into clear, well-defined rules, supplemented by formal criminal liability and provided with well-defined penalties, it has lost its own peculiar character and has moved into the sphere of criminal law - in the same manner as (the law on) extradition has moved from international to criminal law. This prospect could also help to accept prosecutions under international law: they contribute to finding a more clear definition of the behaviour to be punished and thus open the door to formal criminal law, with its more strict application of the nullum crimen rule. ${ }^{32}$

This construction of trial and punishment under international law has been recognised in 1954, in Art. 7(2) of the European Convention on Human Rights:

This article shall not prejudice the trial and punishment of any person for any act or omission which, at the time when it was committed, was criminal according to the general principles of law, recognised by civilised nations. ${ }^{33}$

Here we have to do with the most serious category of criminal behaviour that can be imagined; whoever acts in this way knows that, if he is caught, he can expect a severe - maybe even the most severe - punishment. It would be highly unpractical, for that reason unacceptable and moreover dogmatically erroneous, to require that prospective war criminals should beforehand be able to calculate more exactly the punishment they could expect. It would be useless too; maybe people can be kept from committing war crimes by the knowledge that they will be caught and prosecuted, but they surely will not be kept back by knowledge of the sanction they can expect. In this field, sanctions will not have a preventive effect; they are purely retributive.

As we already explained, as soon as international criminal law, as part of international law, has developed into

32. J. Nilsson, 'The Principle Nullum Crimen Sine Lege', in O. Olusanya (ed.), Rethinking International Criminal Law; the Substantive Part (2007), at 41 and 64, with more literature.

33. See also Art. $15 \mathrm{lid} 2$ IVBPR and e.g. K.S. Gallant, The Principle of Legality in International and Comparative Criminal Law (2009), at 175-200 and 202-11.

common criminal law, one may expect more, especially clear-cut rules which punishments may be given, and in what measure, and also what kinds of aggravating or alleviating circumstances could be accepted. ${ }^{34}$

In short, the nullum crimen, nulla poena rule does apply in international law but only insofar that suspects should be able to foresee for what kind of activities they will be punished, if caught, and what their punishment could be; so it has a far less specific content and will be satisfied much easier than in criminal law. ${ }^{35}$ This approach could - and in our opinion, probably would have been used in criminal proceedings against Wilhelm II.

\section{Immunity of (Former) Heads of State}

Without any doubt under international law a head of state enjoys immunity; he cannot be prosecuted, not within his own country (the King can do no wrong), neither by others, not for what he did in his official capacity, nor for what he did in a private capacity. In the period immediately after the Great War, this rule was even more clear-cut as nowadays. ${ }^{36}$ The Kaiser, however, had abdicated, to prevent being disposed by his own compatriots. With his abdication, his immunity ended; but did it also end for what he had done in his former capacity as head of state? Some authors answered in the negative; Hankel $^{37}$ thought there was around 1918 so much discussion on this subject that this would have been sufficient reason for a trial of Wilhelm to run aground. But can supreme offences against international morality and the sanctity of treaties and serious infringements upon the law and customs on war be committed in an official capacity? We fear that the answer has to be affirmative ${ }^{38}$ - although the Amsterdam Court of Appeals in a recent case decided otherwise. It found that committing such offences can never be the task of a head of state; ${ }^{39}$ but task and capacity are quite different notions. Obviously the reasoning of the Allied Powers has been that it was no longer acceptable to let these kinds of criminals go scot-free. It is clear that they not only denied them immunity after their abdication or disposal but even

34 (2001), at 314-18

35. Compare e.g. Gallant, above n. 34, at 57.

36. More in e.g. R. van Alebeek, The Immunity of States and Their Officials in International Criminal Law and International Human Rights Law (2008).

37. G. Hankel, Die Leipziger Prozesse (2003), at 83/87 (with literature).

38. In the same sense De Lapradelle and Larnaude, above n. 6, at 141.

39. Court of Appeal Amsterdam 20 November 2000, LJN AA8395 rov. 4.2, on the Surinam 'december-murders'. 
wished to prosecute them when they were still in power. ${ }^{40}$ There was some relation with the exception of superior orders (to be discussed hereafter): when one did accept such an exception, it would be unacceptable that the source of these orders would enjoy immunity. For a head of state, this would result in a special legal responsibility as supreme commander. ${ }^{41}$

Whatever might have been its reasoning, in our opinion it is highly improbable that a court would have granted Wilhelm II immunity for what he did as head of the German Reich. Although the American members of the Commission on Responsibilities dissented, their own president Wilson after all accepted that Wilhelm would be prosecuted, and the Dutch government did not refuse Wilhelms' extradition for his immunity. ${ }^{42}$ Actually it took some time before a court made clear that former heads of state cannot invoke immunity. Hitler's suicide prevented the Nuremburg Tribunal to decide this point; the world had to wait for the Yugoslavia Tribunal to ratify the conclusions of the 1919 Commission on Responsibility. ${ }^{43}$

\section{Waging War}

What would have been the result of the prosecution under counts 1 and 2 as defined above? Since Aquinas, a large majority of authors, including Thomas Hobbes, Nicolo Macchiavelli, Hugo Grotius, Emerich de Vattel, and Montesquieu held that every state has the right to go to war against other states. Yes, they did try to restrict the actions of the state to a bellum iustum (to be translated as a justified war) but were nearly unanimous that the (heads of) states themselves were the only authorities who could decide if the war they started mas justified. Kant at least admonished the states 'ihre Streitigkeiten auf civile Art, gleichsam durch einen Proceß, nicht auf barbarische (nach Art der Wilden), nämlich durch Krieg, zu entscheiden, ${ }^{44}$ but Hegel, the Prussian

40. Insofar they were supported by German authors, e.g. O. Poensgen who made clear that (in his opinion) immunity only applied in constitutional law, not in international law. 'Bei uns in Deutschland tragen unsere Herrscher (..) dem Feinde gegenüber auch mit ihrer eigenen Person die Verantwortung (..) und wir würden daher eine Ausnahmestellung fremder Staatsoberhaüpter (..) nicht verstehen' ('Strafe gegen Verletzungen des Völkerrechts', Deutsche Strafrechts-Zeitung 1 column 634/639, Dec. 1914). Art. 7 of the Charter of the Nuremburg Tribunal also excluded immunity; the same applies for Art. 27 ICC Statute. The warrant against Omar al-Bashir has been the first against a serving head of state. Compare the opinions of the British Lawlords in the Pinochetcase (24 maart 1999, <www.publications.parliament.uk>; see also Ars Aequi, at 481-88 (2000)) and, with a different result, the ICJ 14 Feb. 2002 in the Congo-case (Ars Aequi, at 829/39 (2002)).

41. So J.W. Garner, International Law and the World War (1920), Vol. 2, at 497 and following pages.

42. So already Ashton and Hellema, above n. 2, at 80

43. Decision on Review of Indictment and Application for Consequential Orders, Prosecutor v. Milosevic and others, Case No. IT-99-37-I, Judge Hunt, 24 May 1999, A.H. Klip and G. Sluiter (ed.), Annotated Leading Cases of International Criminal Tribunals, Vol. 3, at 39, and Decision on Preliminary Motions, Prosecutor v. Milosevic, Case No. IT-99-37-PT. T. Ch. III, 8 November 2001, <www.un.org/icty/>

44. Die Metaphysik der Sitten (1797) § 61 state philosopher, thought that war would purify the state. Neither did later authors, like Bluntschli, ${ }^{45}$ Huber, ${ }^{46}$ and Von Ullmann, ${ }^{47}$ deny the state a right to go to war if it saw fit to do so. Some of them, like Kohler, thought that war is something 'jenseits von Recht und Unrecht'; ${ }^{48}$ Nys and Hall defended the thesis that war is not a subject of international law at all and therefore cannot be prohibited. In any case, a denial of a ius ad bellum is not to be found in the pre-war literature, neither in treaty law. ${ }^{49}$ Art. 1 of the second 1907 Hague convention (Convention concernant la limitation de l'emploi de la force pour le recouvrement de dettes contractuelles, or Drago-Porter Convention) stipulated:

Les Puissances Contractantes sont convenues de ne pas avoir recours à la force armée pour le recouvrement de dettes contractuelles réclamées au Gouvernement d'un pays par le Gouvernement d'un autre pays comme dues à ses nationaux.

This is unmistakably formulated as an exception to a general rule. We conclude that the Special Tribunal under Art. 227 could not have found that waging war was a criminal act. In that case, Wilhelm had to be acquitted from count 1 of the indictment. Had the Court decided otherwise, it would have written new law ${ }^{50}$ and would have been about 70 years ahead of its time. However, between 1914 and 1920 several highly respectable authors did defend that waging war was a criminal act but always when looking for a way to punish Wilhelm! They used simplifications like:

Alors que l'infraction à la paix publique d'un Etat entraîne les peines les plus graves, on ne comprendrait pas qu'une atteinte à la paix du monde demeurât sans sanction. ${ }^{51}$

Here we see the risks of criminal trials under international law in optima forma: without a strict nullum crimen rule, it would be difficult not to give in to public opinion by creating new law and applying it retrospectively. But what about infringement of the neutrality of Belgium and Luxemburg? ${ }^{52}$ The neutrality of Belgium had been guaranteed by the German Reich - was the German Reich free to see this guarantee as no more than a scrap of paper? Or, from a somewhat different point of

45. J.C. Bluntschli, Das moderne Kriegsrecht der civilisirten Staaten, 2nd edn. (1874).

46. M. Huber, Die Staatensuccession. Völkerrechtliche und Staatsrechtliche Praxis im XIX. Jahrhundert (1898).

47. E. von Ullmann, Völkerrecht, Vol. 3 in the series Das öffentliche Recht der Gegenwart (1908).

48. J. Kohler, Grundlagen des Völkerrechts. Vergangenheit, Gegenwart, Zukunft (1918), at 10

49. More literature in W.G. Grewe, Epochen der Völkerrechtsgeschichte (1984), at 623-28.

50. Or, in the view of De Lapradelle and Larnaude, would have accepted the new international law.

51. De Lapradelle and Larnaude, above n. 6, at 149. In the same style A. Mérignhac and E. Lémonon, Le Droit des Gens et la Guerre de 1914-1918 2 (1921).

52. Cfr. L. Zuckerman, The Rape of Belgium. The Untold Story of World War 1 (2004). 
view: could a qualified kind of waging war be defined as a crime: attacking another country, only because this would be useful in conducting war against a third party? And would this breach of the law be even more qualified by an explicit guarantee of neutrality? Some authors thought that even in such a case it could only be for the state itself to decide whether it should honour its word; but much support for this point of view cannot be found. The international respect for and value of treaties as instruments for the arrangement of mutual relations as well as the act of violating an explicit guarantee would - in our view - be enough to conclude that Wilhelm at least could foresee the wrongfulness of this action under the 'nullum crimen' rule as developed above. For that reason, we think it probable that Wilhelm would have been convicted for committing $a$ supreme offence against international morality and the sanctity of treaties by not respecting the neutrality of, at least, Belgium. That also would have been something new but not quite as revolutionary as criminalising the waging of war in general.

\section{Command Responsibility}

Counts 3, 4, and 5 of our indictment elicit another question: in how far would the Kaiser have been responsible for acts, not of his own, but of others under his command? This even today is a hotly debated issue: should we accept command responsibility, and, if so, how far does it reach?

When there is no individual 'Schiess-Befehl', or at least the existence of no individual order can be proved, ${ }^{53}$ criminal liability can only be based on more indirect actions - or lack of actions. We enumerate some possibilities:

- variant 1: gross negligence in preventing infringements upon the laws of war more generally, e.g. by not taking care that all soldiers would know these laws (the written instructions to the German soldiers even denied the fourth 1907 Hague Convention its force of law), or more specific, by not reacting upon reported violations. Such a responsibility could be deducted from the 1907 Hague conventions; who accepts such treaties, like the German Reich did, not only accepts the obligation to follow the rules given therein, but also to enforce its fulfilment by anyone under one's command. Personal negligence of Wilhelm II, however, would be rather hard to prove.

- variant 2: gross negligence by not properly investigating possible infringements and not combating and punishing reported misbehaviour. Already at the end of September 1914 the circles around the Kaiser knew from Allied sources of serious misbehaviour in Belgium. The head of the Kaisers 'Marine-kabinett', admiral G.A. von Müller, confronted by what he saw as allied propaganda, proposed to ask for an objective

53. As in the case of former leaders of the DDR international investigation by the Hague Court of Arbitration. Although he was supported by the Reichskanzler, Secretary of State Von Jagow refused to follow him 'weil wir schon zu viel auf dem Kerbholz haben'. ${ }^{54}$ Would a court doubt that the Kaiser himself knew about all this and leave it at that? Or would the later German investigations, resulting in a highly apologetic report that laid all blame on the Belgians and their government, ${ }^{55}$ be accepted as a sufficient measure?

- variant 3: restricted (or indirect) command (or superior) responsibility: responsibility for any acts one could have known and could have prevented (but, by one's own fault, did not know, and in any case did not prevent). ${ }^{56}$ The roots can be found in the report of the Commission on Responsibility. The Commission held responsible

all authorities, civil or military, belonging to enemy countries, however high their position may have been, without distinction of rank, including the heads of states, who ordered, or, with knowledge thereof and with power to intervene, abstained from preventing or taking measures to prevent, putting an end to or repressing, violations of the laws or customs of war (it being understood that no such abstention should constitute a defence for the actual perpetrators).

- variant 4: general command responsibility, as defended by the German patriot Poensgen, who wanted to punish 'die Leitung der Polizei, die Ausschreitungen geduldet hat, Verwaltungsbehörden, welche den Franktireurkrieg unterstützt haben, Befehlshaber, in deren Truppen- oder Flottenteilen völkerrechtswidrige Handlungen vorgekommen sind' ${ }^{57}$ Of course, he had his eye on Belgian and French authorities, but this does not alter the principle.

Whatever position the Court would have taken, it would have created something new.

\section{The Submarine War}

Very difficult should have been the discussions on the submarine war. Was submarine war against the ius in bello? But did a ius in bello exist for war on and under the

54. Regierte der Kaiser? Kriegstachebücher, Aufzeichnungen und Briefe des Chefs des Marine-Kabinetts Admiral Georg Alexander von Müller, 2nd edn. (1959), at 62-63.

55. Die völkerrechtswidrige Führung des belgischen Volkskrieges (1915).

56. See e.g. the Yamashita-case after WW II, E. van Sliedregt, The Criminal Responsibility of Individuals for Violations of International Humanitarian law (2003); R. Cryer et al., International Criminal Law and Procedure (2007) under 15.8; A.H.J. Swart, 'De strafrechtelijke aansprakelijkheid van meerderen in het internationale humanitaire recht', in M. Dolman e.a. (red.), Geleerde lessen (Liber Amicorum S.A.M. Stolwijk (2007), at 213-34 and M. Daman, Aansprakelijkheid van militaire en civiele leiders, in Internationaal Humanitair recht in de kijker (2008), at 57-68 (all with more literature).

57. Loco citato. 
seas? Great Britain had been successful in preventing any treaty law on this subject; could nevertheless a sufficient clear and generally accepted corpus of customary law on this subject be defined? Looking back in all objectivity it is highly doubtful whether on the basis of international law an affirmative answer could have been given. If not, the Court was sure to be severely criticised; but from the other side it probably could not convict Wilhelm on this point without creating new law. And what about special aspects, like the intentional destruction of neutral ships and the order to the German submarines not to rescue enemy crews, because this would endanger themselves in a too high degree?

\section{Sanctions}

The Versailles Treaty left it to the Court 'to fix the punishment which it considers should be imposed' ('Il lui appartiendra de determiner la peine qu'il estimera devoir être appliquée').

This covers all sanctions from a simple fine to imprisonment for life and even death; but the tribunal not only had to determine what sanction(s) could be imposed but also to fix their terms, for instance in case it would decide that (temporary) imprisonment 'should be imposed'. It is clear that in this respect Art. 227 differed from Art. 228. As Art. 227 dealt with new and, up to those years, unknown crimes, an international tribunal had to be introduced, and there was no sanction prescribed in any national or in international law. Art. 228, on the contrary, dealing with violations of the laws and customs of war, refers to a much clearer defined part of the law, but relies also on existing military tribunals that could apply existing national law; therefore, in Art. 228, the Treaty could also refer to punishments 'laid down by law'. It is to be noted that in those days military law in nearly all countries relied rather heavily on the death penalty.

Art. 227 might be criticised for violation of legality, especially of the nullum poena sine lege principle. However, this principle has not the same theoretical 'weight' concerning the sanction as it has concerning criminal liability as such. Under Art. 27 of the Charter for the Nuremburg Tribunal, but even under Art. 77 of the Rome Statute of the ICC, there is a certain open decision for the tribunal to fix the penalty, although in the ICC Statute some boundaries have been fixed. The criticism from the Japanese and American members of the Commission on Responsibility on Art. 227, derived from this nullen crimen sine lege principle, was indeed directed to the definition of the (proposed) 'crimes', not to the determination of sanctions. Nevertheless, that Art. 227 Treaty did not even indicate what kind of sanc- tion might be fixed by the tribunal is, in the views of today, a rather weak point. ${ }^{58}$

Are there any more specific indications about the sanction(s) that might have been at stake? The Allied Powers wanted to assure Wilhelm a fair trial, as part of their attempt to put him to trial in a judicial (criminal) process for allegations on - more or less - moral grounds. One can argue that the guarantee that the sanction will not be (too) disproportionate in relation to the facts and crimes to which an accused has been found guilty may come within the scope of fair trial where the 'guarantees essential to the right of the defence', underlined in Art. 227 of the Treaty, are also related to the fact finding and discussion about these facts during trial, related to the determination of the appropriate sanction, the extent of punishment, the terms of imprisonment, etc. ${ }^{59}$

Could deportation of Wilhelm to - for instance - the Falkland Islands have been an appropriate sanction and a sanction that he might have expected? This will hardly be the case. Except in France in those days deportation was not a criminal punishment under any national criminal law anymore. Moreover the deportation of Napoleon was mainly a safety measure because this French ex-emperor was still considered a danger for the international order and peace.

Given the situation in Germany and Wilhelm exile in the Netherlands, it is understandable that this was not an argument that was in anyway taken into consideration. ${ }^{60}$ We hear from Lloyd George that especially Clemenceau was not very interested in punishments; his main wish being that Wilhelm would be brandmarked and ostracised as a 'universal outlaw'. ${ }^{61}$ Garner came to the same result by simple legal reasoning; he took the view that Wilhelm, if he was not prosecuted and convicted for a crime under the Penal Code, could not be sentenced, as (in his view) required by Art. 228 of the Versailles Treaty, to 'punishments laid down by law', 'and since the law of nations prescribes no penalties for offences against international morality or the sanctity of treaties' the Court would have but one option, to wit 'a formal pronouncement, stigmatizing (Wilhelm) as a treaty breaker (...) and holding him up to the execration of mankind. ${ }^{92}$ But Garner was wrong. The Commission on Responsibility asked for 'such punishment or punishments as may be imposed for such an offence or offences by any court in any country represented on the tribunal or in the country of the convicted person' 63 - and there is no reason to suppose that the treatymakers took another position, although they also wanted to try Wilhelm for supreme offences against international morality and the sanctity of treaties.

For elaboration and discussion of the pro's and contra's of the nulla poena rule as applicable to the discussed provision of Art. 227 of the Versailles Treaty and to (modern) crimes under international law in general: Gallant (2009), above n. 34 at 56-59 and chapter 7.c. respectively.

59. Safferling, above n. 35, at 314-18.

60. Pompe, above n. 2, at 169.

61. Above n. 2, at 98

62. 'Punishment of Offenders Against the Laws and Customs of War', 14 AJIL, 70-94, at 92 (1920).

63. Report at 122. 
Had the tribunal, in case of conviction, to apply any sanction, or would a conviction without a sanction be an option too? Do the words 'fix the punishment which it considers should be imposed' leave this possibility? One might argue that the Allied Powers were primarily interested in making clear that waging war and breaching a guaranteed neutrality were criminal under international law and would have accepted 'a formal condemnation', as it had been proposed by the Commission on Responsibility. But would this, in those years, really have been a realistic option?

Anyway the combination of Artt. 227 and 228 gave the Court as much liberty as later the Nuremburg Court ${ }^{64}$ and the Yugoslavia Tribunal would have. It really is a pity we do not know how it would have used this liberty.

\section{Conclusion}

We repeat: the above gives not more than a first very global outline of what could have happened when Wilhelm really had been prosecuted. In any case, it seems clear that, unless the (rather improbable) possibility of a complete acquittal, the Court would have created an important piece of international criminal law and would have levelled the path for the Nuremburg Court. Could it also have made history take a different turn? We do not think so. The power of the courts, and of law in general, is limited; probably the deterrent effect of convictions in the field of crimes against humanity is not much more than zero. But perhaps the tribunal would have boosted up morality, and in any case it would have considerably accelerated developments in criminal law.

A last word. The Second World War was a war against evil that had overcome Germany; but the Great War was carried on against the German people itself. Although Pangerman thinking ${ }^{65}$ had a strong influence on German politics in the decade before 1914, not many of its adherents were in power during the Great War and for that simple reason would not have been prosecuted. Perverted nationalistic ideas like those propagated by Kohler, and those uttered sometimes by Wilhelm himself, really started prospering in the times of Hindenburg and Hitler; the turn of their protagonists to stand trial still had to come after 1945. One has to keep in mind that the type of defendants in Nuremburg was quite different from the persons the Allied Powers intended to prosecute after 1918. It is highly improbable that this would not have influenced the outcome.

The Charter of this Tribunal (Art. 27) mentioned the death penalty or any other punishment that the Tribunal would think fit. See the comment by Quaritsch, above n. 27, at 162: 'Das Kriegsvölkerrecht enthält jedoch keine 'poena', nämlich keinen Strafrahmen, der Richter ist in diesen Fällen auf die Strafdrohungen des nationalen Rechts angewiesen. Man kann nicht annehmen, das (Gericht) könne die Strafe zwischen Geldbusse und Tot durch Erhängen frei und ohne normative Grundlage wählen und festsetzen'.

65. Pangermanism: theories that German 'Kultur' and German 'Blut' were superior, implicating that Germans should rule the world. 